
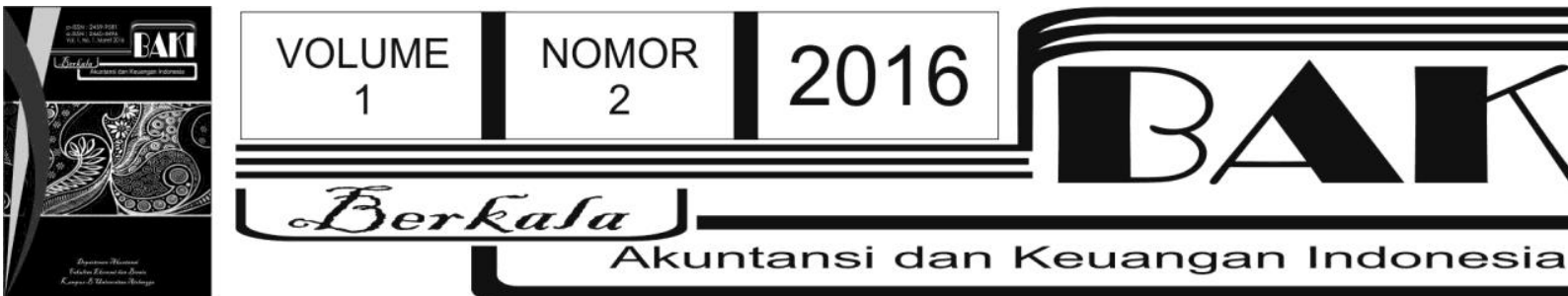

\title{
Berkata
}

Akuntansi dan Keuangan Indonesia

\section{Pengaruh Likuiditas, Solvabilitas, Profitabilitas, dan Rencana Manajemen terhadap Opini Audit Going Concern (Studi Empiris Perusahaan Manufaktur di BEl)}

\author{
Christian Lie*, Rr. Puruwita Wardani, Toto Warsoko Pikir \\ *Universitas Katolik Widya Mandala Surabaya \\ ‘christian_lie1993@yahoo.com
}

INFO ARTIKEL

Histori Artikel:

Tanggal Masuk 9 November 2015

Tanggal Diterima 25 Juli 2016

Tersedia Online 30 September 2016

Kata Kunci:

likuiditas;

solvabilitas;

profitabilitas;

rencana manajemen;

opini audit going concern

\begin{abstract}
A BSTRAK
Auditor bertugas untuk menilai kewajaran laporan keuangan. Selain mendapatkan informasi mengenai kewajaran laporan keuangan, para pengguna juga dapat mengetahui informasi mengenai kemampuan perusahaan dalam mempertahankan kelangsungan usahanya yaitu melalui opini audit going concern. Tujuan penelitian ini untuk menganalisis pengaruh likuiditas, solvabilitas, profitabilitas dan rencana manajemen terhadap penerimaan opini audit going concern. Obyek penelitian ini adalah perusahaan manufaktur yang terdaftar di BEI dari tahun 20102012. Sampel dipilih dengan metode purposive sampling. Dengan menggunakan analisis regresi logistik, hasilnya adalah solvabilitas dan rencana manajemen berpengaruh terhadap penerimaan opini audit going concern, sedangkan likuiditas dan profitabilitas tidak berpengaruh terhadap penerimaan opini audit going concern.
\end{abstract}

\section{Pendahuluan}

Laporan keuangan sangat penting bagi para penggunanya baik dari pihak internal maupun eksternal dalam mengambil sebuah keputusan. Bagi investor dan kreditor laporan keuangan diharapkan dapat memberikan informasi yang akurat mengenai kondisi perusahaan. Laporan keuangan merupakan cerminan dari bentuk pertanggungjawaban dari manajemen perusahaan kepada pemilik perusahaan, karena sesuai dengan teori keagenan dikatakan bahwa pemilik (prinsipal) memberikan delegasi kepada manajemen (agen) untuk melaksanakan kepentingan pemilik (Jensen dan Meckling 1976). Hal ini menyebabkan muncul sebuah kondisi yang disebut asimetri informasi, dimana agen sebagai pengelola perusahaan dianggap memiliki informasi yang lebih banyak mengenai perusahaan dibandingkan prinsipal. Karena adanya asimetri 
informasi ini, maka tidak menutup kemungkinan terjadinya konflik kepentingan antara agen dengan prinsipal untuk saling mencoba memanfaatkan kelemahan pada pihak lain demi kepentingan sendiri. Auditor dipandang sebagai pihak yang mampu menjembatani kepentingan pihak prinsipal dengan pihak agen (Setiawan 2006 dalam Susanto 2009). Sebagai pihak yang independen, auditor memiliki tanggung jawab untuk mengevaluasi apakah kebijakan yang diambil oleh manajemen telah sesuai dengan kehendak prinsipal. Auditor akan memeriksa kewajaran laporan keuangan yang dibuat oleh manajemen.

Laporan keuangan yang dikeluarkan oleh manajemen akan lebih dapat dipercaya oleh pengguna laporan keuangan apabila laporan keuangan tersebut telah mendapatkan pernyataan/opini dari auditor independen atas kewajaran laporan keuangan tersebut. Institut Akuntan Publik Indonesia (IAPI) dalam PSA 30, SA 341 (IAPI 2011) menyatakan bahwa auditor memiliki tanggung jawab untuk mengevaluasi kemampuan etitas dalam mempertahankan kelangsungan hidupnya dalam periode waktu pantas (satu tahun sejak tanggal laporan keuangan tersebut diaudit), selain itu dinyatakan juga dalam PSA 30, SA 341 (IAPI 2011) tersebut bahwa going concern dapat dipakai sebagai asumsi dalam pelaporan keuangan sepanjang tidak terbukti adanya informasi yang menunjukkan hal yang berlawanan. Biasanya informasi yang secara signifikan dianggap berlawanan dengan asumsi kelangsungan hidup suatu badan usaha adalah berhubungan dengan ketidakmampuan satuan usaha dalam memenuhi kewajibannya pada saat jatuh tempo tanpa melakukan penjualan sebagian besar aktiva kepada pihak luar secara bisnis biasa, restrukturisasi utang, perbaikan operasi yang dipaksakan dari luar atau kegiatan serupa lainnya (IAPI 2011). Opini audit going concern merupakan opini yang dikeluarkan auditor karena auditor memiliki keraguan atas kelangsungan usaha perusahaan (Sutedja 2010). Beberapa peristiwa seperti terjadinya kerugian operasional yang cukup besar, kurangnya modal kerja, ketidakmampuan perusahaan dalam melunasi kewajiban saat jatuh tempo, kehilangan pelanggan utama dan tuntutan hukum dapat menimbulkan keraguan auditor akan kelangsungan hidup perusahaan (Arens 2011: 377). Jika terdapat peristiwa yang dapat menyebabkan auditor ragu atas kelangsungan hidup perusahaan, maka auditor harus memberikan opini mengenai hal tersebut. Opini auditor atas keraguan kelangsungan hidup perusahaan disebut opini going concern. PSA No. 30 SA 341 (IAPI 2011) menyatakan bahwa jika seorang auditor meragukan kemampuan sebuah perusahaan dalam mempertahankan kelangsungan usahanya, maka auditor harus memperoleh informasi tentang bagaimana rencana manajemen perusahaan tersebut dan mempertimbangkan apakah rencana tersebut dapat secara efektif dilaksanakan. Berdasarkan PSA No. 30 SA 341 (IAPI 2011) auditor dapat mempertimbangkan untuk memberikan pernyataan tidak memberikan pendapat (disclaimer opinion) jika auditor ragu akan kelangsungan hidup perusahaan dan manajemen perusahaan tidak memiliki rencana atau 
rencana dari manajemen dinilai tidak efektif untuk mengatasi dampak dari peristiwa yang menyebabkan keraguan auditor, serta pendapat wajar tanpa pengecualian dengan bahasa penjelas (unqualified opinion with explanatory language) dapat diberikan auditor, apabila auditor ragu akan kelangsungan hidup perusahaan tetapi auditor menilai rencana manajemen efektif dalam mengatasi dampak peristiwa tersebut dan rencana tersebut diungkapkan dalam catatan atas laporan keuangan, sedangkan apabila auditor ragu akan kelangsungan hidup perusahaan dan menilai rencana manajemen efektif untuk mengatasi dampak dari peristiwa yang menyebabkan keraguan tersebut namun pihak manajemen tidak mengungkapkan keadaan tersebut dalam catatan atas laporan keuangan, maka auditor dapat mempertimbangkan untuk memberikan pernyataan pendapat wajar dengan pengecualian (qualified opinion) atau pendapat tidak wajar (adverse opinion).

Pendapat atas kemampuan perusahaan mempertahankan keberlanjutan usahanya menjadi sangat penting untuk diungkapkan, karena laporan keuangan sebuah perusahaan disusun menggunakan asumsi bahwa perusahaan akan tetap beroperasi untuk jangka waktu yang lama, sehingga apabila muncul keraguan dari auditor terhadap kemampuan perusahaan dalam mempertahankan kelangsungan hidupnya, maka hal tersebut harus segera diungkapkan kepada publik. Hal ini bertujuan agar para pemakai laporan keuangan tidak sampai salah dalam mengambil keputusan bisnis.

Auditor dalam menilai kemampuan sebuah perusahaan harus mempertimbangkan banyak hal, baik informasi yang bersifat kuantitatif dan kualitatif. Informasi yang bersifat kuantitatif yang dapat dipakai oleh auditor diantaranya adalah rasio keuangan seperti likuiditas, solvabilitas dan profitabilitas. Sedangkan untuk informasi yang bersifat kualitatif yang dapat dipakai auditor diantaranya adalah kondisi-kondisi yang mungkin dapat mempengaruhi operasional sehari-hari perusahaan seperti rencana manajemen, tuntutan hukum dan lainnya.

Likuiditas merupakan suatu indikator untuk mengukur kemampuan perusahaan untuk membayar semua kewajiban finansial jangka pendek pada saat jatuh tempo dengan menggunakan aktiva lancar yang tersedia (Syamsuddin 2001: 41). Apabila sebuah perusahaan tidak memiliki kemampuan melunasi kewajiban jangka pendeknya, maka operasional perusahaan akan terganggu dan hal ini dapat menyebabkan auditor ragu atas kemampuan perusahaan dalam mempertahankan kelangsungan usahanya. Auditor, dalam hal ini, dipandang sebagai pihak independen yang bertugas untuk menilai kewajaran laporan keuangan agar laporan keuangan dapat dipakai oleh prinsipal untuk mengambil keputusan bisnis yang tepat. Penelitian yang dilakukan oleh Susanto (2009) dan Sussanto dan Aquariza (2012) menyatakan bahwa likuiditas yang diproksikan dengan current ratio tidak berpengaruh terhadap penerimaan opini audit going concern. Hal ini disebabkan karena auditor dalam memberikan opini audit going concern tidak hanya melihat likuiditas perusahaan, akan tetapi 
lebih cenderung melihat kondisi keuangan perusahaan secara keseluruhan (Susanto 2009). Namun hasil penelitian tersebut berbeda dengan hasil penelitian yang dilakukan Januarti dan Fitrianasari (2008) yang menyatakan bahwa likuiditas perusahaan berpengaruh terhadap penerimaan opini audit going concern dari auditor.

Solvabilitas merupakan rasio yang digunakan untuk mengukur besarnya total aktiva perusahaan yang dibiayai oleh kreditur (Sundjaja dan Barlian 2003: 140). Penelitian terdahulu yang dilakukan oleh Susanto (2009), Sussanto dan Aquariza (2012) dan Sutedja (2010) menyatakan bahwa solvabilitas yang diproksikan dengan debt to assets ratio berpengaruh terhadap penerimaan opini audit going concern dari auditor. Namun hasil penelitian ini berbeda dengan penelitian yang dilakukan Rudyawan dan Badera (2009). Hal ini menjadi lebih menarik untuk diteliti lebih lanjut, karena apabila sebuah perusahaan memiliki rasio solvabilitas yang tinggi cenderung memiliki hutang yang tinggi pula. Hal ini akan meningkatkan resiko yang mungkin akan dihadapi oleh perusahaan, terutama dalam hal pembayaran hutang dan bunga. Perusahaan yang memiliki hutang yang tinggi akan cenderung mengalami kesulitan keuangan. Hal ini secara tidak langsung akan menimbulkan keraguan dari auditor atas kemampuan going concern perusahaan. Auditor sebagai pihak ketiga yang independen berkewajiban untuk menilai kewajaran laporan keuangan dan juga kelangsungan usaha perusahaan agar para pengguna laporan keuangan tidak salah dalam mengambil suatu keputusan.

Profitabilitas merupakan kemampuan perusahaan dalam menghasilkan keuntungan dengan seluruh aktiva yang tersedia (Syamsuddin 2001: 63). Laba sering digunakan sebagai penilai kinerja dari sebuah perusahaan. Profitabilitas sebuah perusahaan juga akan sangat mempengaruhi keputusan bisnis dari investor/kreditor. Penelitian terdahulu yang dilakukan Susanto (2009), Kristiana (2012) dan Sutedja (2010) menyatakan bahwa profitabilitas berpengaruh terhadap penerimaan opini going concern. Namun hasil dari penelitian tersebut berbeda dengan penelitian yang dilakukan oleh Januarti dan Fitrianasari (2008) dan Sussanto dan Aquariza (2012). Hal ini sangat menarik untuk diteliti, karena apabila sebuah perusahaan tidak memiliki kemampuan untuk menghasilkan laba, maka auditor cenderung akan memberikan opini going concern. Auditor sebagai pihak ketiga yang independen memiliki tanggung jawab untuk menilai kewajaran atas laporan keuangan yang diterbitkan, sehingga diharapkan pengguna laporan keuangan akan dapat mengambil keputusan bisnis dengan tepat.

Rencana manajemen merupakan salah satu informasi yang bersifat kualitatif yang juga harus dijadikan sebagai pertimbangan bagi auditor dalam memberikan opini going concern. Dalam teori keagenan dijelaskan bahwa hubungan keagenan sebagai suatu kontrak antara satu atau lebih prinsipal yang mengikat pihak lain (agen) untuk melaksanakan kepentingan prinsipal dengan cara prinsipal memberikan delegasi kepada agen untuk melaksanakan kepentingan prinsipal (Jensen dan Meckling 1976). Keputusan yang diambil manajemen dalam menjalankan 
sebuah perusahaan mungkin saja tidak sesuai dengan kehendak dari pemegang saham, hal ini disebabkan adanya perbedaan kepentingan diantara kedua belah pihak.

Rencana manajemen untuk mengatasi masalah going concern yang disusun oleh manajemen perusahaan dapat dibagi menjadi dua kelompok yaitu rencana manajemen berbasis keuangan dan rencana manajemen untuk memperbaiki kinerja operasional. Rencana manajemen berbasis keuangan lebih mengarah kepada upaya manajemen perusahaan untuk menambah sumber dana perusahaan baik dengan cara menerbitkan saham baru hingga merestrukturisasi hutang, selain itu manajemen juga dapat menyusun rencana untuk memperbaiki kinerja operasional perusahaan agar lebih menguntungkan melalui penghematan biaya, peningkatan penjualan hingga pengeluaran produk baru. Penelitian mengenai rencana manajemen sebelumnya telah dilakukan oleh Setyowati (2013) yang menyatakan bahwa rencana manajemen berupa strategi emisi saham dan strategi menarik/merestrukturisasi hutang berpengaruh negatif terhadap penerimaan opini going concern, sedangkan rencana manajemen berupa strategi pengurangan biaya justru menambah keraguan auditor akan kelangsungan usaha perusahaan, dan rencana manajemen berupa strategi untuk menjual aktiva tetap tidak mempengaruhi auditor dalam memberikan opini going concern.

Penelitian terdahulu menunjukkan hasil yang tidak konsisten, sehingga penelitian mengenai pengaruh likuiditas, solvabilitas, profitabilitas dan rencana manajemen terhadap opini audit going concern masih menarik untuk diteliti. Penelitian ini menggunakan sampel perusahaan manufaktur yang tercatat di Bursa Efek Indonesia (BEI) pada tahun 2010-2012 karena jumlah perusahaan manufaktur lebih banyak dibanding perusahaan sektor lainnya. Berdasarkan latar belakang di atas, maka rumusan masalah dalam penelitian ini adalah apakah likuiditas, solvabilitas, profitabilitas, dan rencana manajemen sebuah perusahaan berpengaruh terhadap penerimaan opini going concern dari auditor independen? Tujuan penelitian ini adalah untuk menganalisis likuiditas, solvabilitas, profitabilitas, dan rencana manajemen dalam pengaruhnya terhadap penerimaan opini going concern.

\section{Tinjauan Pustaka}

\subsection{Teori Keagenan (Agency Theory)}

Jensen dan Meckling (1976) menggambarkan hubungan keagenan antara pemilik (principal) dan manajer (agent) dimana pemilik menginginkan agar manajer bertindak untuk kepentingan pemilik, namun adakalanya manajer bertindak untuk kepentingan sendiri. Agar manajer dapat bertindak sesuai dengan kepentingan pemilik maka diperlukan pengawasan untuk kinerja dari manajemen. Laporan keuangan merupakan cerminan dari kinerja 
manajemen. Auditor sebagai pihak yang independen diperlukan untuk menilai kewajaran dari laporan keuangan suatu perusahaan. Auditor akan menerbitkan opini atas kewajaran laporan keuangan serta opini audit going concern apabila suatu perusahaan sedang mengalami masalah keuangan. Pemberian opini audit going concern tersebut dapat juga diartikan bahwa auditor memberikan informasi penting bagi pengguna laporan keuangan mengenai kelangsungan usaha perusahaan.

\subsection{Penelitian Terdahulu dan Pengembangan Hipotesis}

Penelitian terdahulu mengenai opini audit going concern telah dilakukan oleh Januarti dan Fitrianasari (2008), Rudyawan dan Badera (2009), Susanto (2009), Sutedja (2010), Sussanto dan Aquariza (2012), Kristiana (2012), Setyowati (2013). Januarti dan Fitrianasari (2008) menganalisis pengaruh dari rasio keuangan (rasio likuiditas, rasio solvabilitas, rasio aktivitas, rasio nilai pasar, rasio profitabilitas dan rasio pertumbuhan penjualan) dan rasio non-keuangan (audit lag, auditor client-tenure, opini audit going concern tahun lalu, repurtasi KAP dan ukuran perusahaan) terhadap opini audit going concern. Hasil penelitian Januarti dan Fitrianasari (2008) menyatakan bahwa audit lag, opini audit going concern tahun lalu dan rasio likuiditas berpengaruh terhadap penerimaan opini audit going concern dari auditor, sedangkan auditor client-tenure, repurtasi KAP, ukuran perusahaan, rasio nilai pasar, rasio pertumbuhan penjualan, rasio solvabilitas, rasio profitabilitas dan rasio aktivitas tidak berpengaruh terhadap penerimaan opini audit going concern.

Persamaan penelitian ini dengan penelitian Januarti dan Fitrianasari (2008) adalah samasama meneliti pengaruh rasio likuiditas, rasio solvabilitas dan rasio profitabilitas terhadap opini audit going concern. Perbedaannya adalah penelitian ini tidak memasukkan rasio aktivitas, rasio pertumbuhan penjualan, rasio nilai pasar, audit lag, auditor client-tenure, opini audit going concern tahun lalu, repurtasi KAP dan ukuran perusahaan untuk diteliti dan adanya penambahan variabel independen lainnya yaitu rencana manajemen.

Rudyawan dan Badera (2009), menganalisis pengaruh model prediksi kebangkrutan, pertumbuhan perusahaan, solvabilitas perusahaan dan repurtasi auditor terhadap opini audit going concern. Hasil dari penelitian Rudyawan dan Badera (2009) menyatakan bahwa pertumbuhan perusahaan, solvabilitas perusahaan dan repurtasi auditor tidak berpengaruh terhadap penerimaan opini audit going concern, sedangkan model prediksi kebangkrutan berpengaruh terhadap penerimaan opini audit going concern.

Persamaan penelitian ini dengan penelitian Rudyawan dan Badera (2009) adalah samasama meneliti pengaruh solvabilitas terhadap opini audit going concern. Perbedaannya adalah penelitian ini tidak memasukkan model prediksi kebangkrutan, pertumbuhan perusahaan dan 
repurtasi auditor untuk diteliti dan adanya penambahan variabel independen lainnya yaitu likuiditas, profitabilitas dan rencana manajemen.

Susanto (2009), melakukan penelitian mengenai faktor-faktor yang mempengaruhi penerimaan opini audit going concern yang dilakukan dengan mengamati kondisi keuangan perusahaan, current ratio, quick ratio, return on assets, debt to total assets, long term debt to total assets, kualitas audit, opini audit tahun sebelumnya, debt default dan opinion shopping. Hasil dari penelitian tersebut menunjukkan bahwa kondisi keuangan dan return on assets berpengaruh negatif terhadap penerimaan opini audit going concern. opini audit tahun sebelumnya dan debt to total assets memiliki pengaruh positif terhadap penerimaan opini audit going concern, sedangkan variabel lainnya tidak mempengaruhi opini audit going concern.

Persamaan penelitian Susanto (2009) dengan penelitian ini adalah sama-sama meneliti pengaruh current ratio, debt to total assets dan return on assets terhadap penerimaan opini audit going concern. Perbedaannya adalah penelitian ini tidak memasukkan kondisi keuangan perusahaan, quick ratio, long term debt to total assets, kualitas audit, opini audit tahun sebelumnya, debt default dan opinion shopping untuk diteliti dan adanya penambahan variabel independen lainnya yaitu rencana manajemen.

Sutedja (2010), melakukan penelitian mengenai faktor-faktor yang berpengaruh terhadap penerimaan opini audit going concern yang dilakukan dengan mengamati kualitas audit, likuiditas, solvabilitas, profitabilitas, opini audit sebelumnya dan pertumbuhan perusahaan. Hasil penelitian Sutedja (2010) tersebut menyatakan bahwa profitabilitas, solvabilitas dan opini audit sebelumnya berpengaruh terhadap penerimaan opini audit going concern. Sedangkan kualitas audit, likuiditas dan pertumbuhan perusahaan tidak berpengaruh terhadap penerimaan opini audit going concern.

Persamaan penelitian ini dengan penelitian Sutedja (2010) adalah sama-sama meneliti pengaruh rasio keuangan (likuiditas, solvabilitas dan profitabilitas) terhadap opini audit going concern. Perbedaannya adalah penelitian ini tidak memasukkan variabel kualitas audit, opini audit sebelumnya dan pertumbuhan perusahaan untuk diteliti. Dalam penelitian ini terdapat penambahan variabel independen lainnya yaitu rencana manajemen. Sussanto dan Aquariza (2012), menganalisis pengaruh opini audit sebelumnya, kualitas auditor, profitabilitas, likuiditas dan solvabilitas terhadap opini audit going concern. Hasil dari penelitian Sussanto dan Aquariza (2012) menyatakan bahwa kualitas auditor, profitabilitas dan likuiditas tidak berpengaruh terhadap penerimaan opini audit going concern, sedangkan opini audit sebelumnya dan solvabilitas berpengaruh terhadap penerimaan opini audit going concern.

Persamaan penelitian ini dengan penelitian Sussanto dan Aquariza (2012) adalah samasama meneliti pengaruh likuiditas, profitabilitas dan solvabilitas terhadap opini audit going concern. Perbedaannya adalah penelitian ini tidak memasukkan opini audit sebelumnya dan 
kualitas auditor untuk diteliti dan adanya penambahan variabel independen lainnya yaitu rencana manajemen.

Kristiana (2012), menganalisis pengaruh ukuran perusahaan, profitabilitas, likuiditas dan pertumbuhan perusahaan terhadap opini audit going concern. Hasil dari penelitian Kristiana (2012) menyatakan bahwa ukuran perusahaan tidak berpengaruh terhadap penerimaan opini audit going concern, sedangkan profitabilitas, likuiditas dan pertumbuhan perusahaan berpengaruh terhadap penerimaan opini audit going concern.

Persamaan penelitian ini dengan penelitian Kristiana (2012) adalah sama-sama meneliti pengaruh likuiditas dan profitabilitas terhadap opini audit going concern. Perbedaannya adalah penelitian ini tidak memasukkan ukuran perusahaan dan pertumbuhan perusahaan untuk diteliti dan adanya penambahan variabel independen lainnya yaitu rencana manajemen.

Penelitian Setyowati (2013) bertujuan untuk memberikan bukti empiris pengaruh rencana manajemen yang terdiri dari rencana emisi saham, rencana menarik hutang, rencana menjual aktiva dan rencana mengurangi/menunda pengeluaran terhadap penerimaan opini audit going concern. Hasil penelitian Setyowati (2013) menyatakan bahwa rencana manajemen berupa strategi emisi saham dan strategi menarik/merestrukturisasi hutang berpengaruh negatif terhadap penerimaan opini going concern, sedangkan rencana manajemen berupa strategi menjual aset tidak produktif tidak berpengaruh terhadap penerimaan opini audit going concern, dan rencana manajemen berupa strategi untuk mengurangi/menunda pengeluran berpengaruh positif terhadap penerimaan opini audit going concern.

Persamaan penelitian Setyowati (2013) dengan penelitian ini adalah sama-sama meneliti pengaruh dari rencana manajemen terhadap opini audit going concern. Perbedaannya adalah penelitian ini tidak merinci rencana manajemen seperti penelitian terdahulu.

\subsubsection{Pengaruh Likuiditas dengan Penerimaan Opini Audit Going Concern}

Likuiditas merupakan kemampuan sebuah perusahaan dalam melunasi kewajiban jangka pendek yang dimiliki dengan menggunakan aset lancarnya. Laporan keuangan merupakan cerminan dari kinerja manajemen. Manajemen akan berusaha untuk menutupi likuiditas perusahaan yang rendah agar kinerjanya tidak terlihat buruk. Auditor sebagai pihak independen akan memeriksa kinerja manajemen. Semakin rendah kinerja manajemen berupa likuditas maka akan semakin tinggi penerimaan opini audit going concern. Rasio likuiditas dapat diukur dengan menggunakan current ratio. Semakin kecil likuiditas sebuah perusahaan dapat diartikan bahwa perusahaan tersebut tidak mampu melunasi kewajiban jangka pendeknya yang akan segera jatuh tempo. Sebuah perusahaan yang secara konsisten mengalami kerugian operasi cenderung memiliki working capital yang sangat kecil bila dibandingkan dengan total aset. 
Dalam hubungannya dengan opini audit going concern, semakin kecil likuiditas sebuah perusahaan, maka semakin kecil juga kemampuan perusahaan tersebut dalam melunasi kewajiban jangka pendeknya menggunakan aktiva lancar yang dimiliki, hal ini cenderung akan mengakibatkan banyak kredit yang macet, sehingga akan menimbulkan kesangsian bagi auditor atas kelangsungan hidup perusahaan. Sebaliknya, apabila likuiditas perusahaan semakin besar, maka semakin besar juga kemampuan perusahaan dalam melunasi kewajiban jangka pendeknya dengan tepat waktu. Hipotesis ini didukung oleh Hany (2003) dalam Januarti (2008) dan Eko (2005) dalam Januarti (2008), serta Januarti (2008) yang membuktikan bahwa likuiditas berpengaruh negatif terhadap penerimaan opini audit going concern. Perusahaan yang memiliki likuiditas yang rendah menunjukkan bahwa perusahaan tersebut semakin rendah kemampuannya dalam melunasi kewajiban jangka pendeknya dengan tepat waktu, sehingga menyebabkan semakin tinggi kecenderungan auditor memberikan opini audit going concern dalam menilai kelangsungan hidup perusahaan agar pengguna laporan keuangan tidak salah dalam mengambil suatu keputusan, sehingga hipotesis pertama adalah:

H1: Likuiditas berpengaruh negatif terhadap penerimaan opini audit going concern.

\subsubsection{Pengaruh Solvabilitas dengan Penerimaan Opini Audit Going Concern}

Rasio solvabilitas merupakan rasio yang digunakan untuk mengukur besarnya total aset perusahaan yang dibiayai oleh kreditur (Sundjaja dan Barlian 2003: 140). Laporan keuangan merupakan cerminan dari kinerja manajemen. Manajemen akan berusaha untuk menutupi solvabilitas perusahaan yang tinggi dengan cara memanipulasi laporan keuangan agar perusahaan terlihat lebih menguntungkan. Auditor sebagai pihak independen akan memeriksa kinerja manajemen termasuk kemungkinan diberikannya opini audit going concern. Semakin tinggi solvabilitas perusahaan maka akan semakin tinggi pula kemungkinan penerimaan opini audit going concern. Rasio solvabilitas diukur dengan menggunakan rasio debt to total assets. Hubungan solvabilitas dengan opini audit going concern adalah bahwa semakin tinggi rasio solvabilitas sebuah perusahaan maka semakin tinggi pula aset perusahaan yang dibiayai dengan hutang dari kreditur. Solvabilitas yang tinggi akan dapat meningkatkan resiko perusahaan, terutama dalam hal pembayaran hutang dan bunga. Perusahaan yang memiliki hutang yang tinggi akan cenderung mengalami kesulitan keuangan. Hal ini secara tidak langsung akan menimbulkan keraguan dari auditor atas kemampuan going concern perusahaan. Sebaliknya, apabila solvabilitas sebuah perusahaan rendah, maka semakin rendah juga resiko dalam hal pembayaran hutang dan bunga yang dihadapi oleh perusahaan, sehingga tidak akan membuat auditor ragu atas kelangsungan hidup perusahaan. Susanto (2009), Sutedja (2010), serta Sussanto dan Aquariza (2012) membuktikan bahwa solvabilitas 
berpengaruh positif terhadap penerimaan penerimaan opini audit going concern. Berdasarkan uraian diatas maka hipotesis kedua adalah sebagai berikut:

H2: $\quad$ Solvabilitas berpengaruh positif terhadap penerimaan opini audit going concern.

\subsubsection{Pengaruh Profitabilitas dengan Opini Audit Going Concern}

Rasio profitabilitas merupakan rasio yang digunakan dalam mengukur kemampuan sebuah perusahaan dalam memperoleh laba dan mengukur tingkat efisiensi usaha. Laporan keuangan merupakan cerminan dari kinerja manajemen. Manajemen akan berusaha untuk mengungkapkan adanya profit dalam laporan perusahaan. Perusahaan dengan profit yang rendah, bahkan sampai rugi akan menyebabkan perusahaan mengalami kesulitan keuangan sehingga semakin besar kemungkinan perusahaan memperoleh opini audit going concern. Auditor sebagai pihak independen akan berusaha untuk memeriksa kinerja manajemen. Semakin rendah kinerja manajemen berupa profitabilitas maka akan semakin tinggi penerimaan opini audit going concern. Rasio profitabilitas sebuah perusahaan dapat dihitung dengan menggunakan return on assets (ROA). Dalam hubungannya dengan opini audit going concern, semua perusahaan dituntut untuk dapat menghasilkan laba dengan semua sumber daya yang dimiliki, dimana nantinya laba yang dihasilkan akan digunakan untuk mempertahankan kelangsungan usaha perusahaan. Semakin rendah profitabilitas sebuah perusahaan, maka semakin rendah juga kemampuan perusahaan dalam menghasilkan laba sehingga akan menyebabkan keraguan auditor atas kelangsungan usaha perusahaan, sebaliknya, jika profitabilitas perusahaan tinggi, berarti semakin tnggi juga kemampuan perusahaan dalam memperoleh laba sehingga tidak akan muncul keraguan akan kelangsungan usaha dari perusahaan tersebut. Susanto (2009), Kristiana (2012), dan Sutedja (2010) membuktikan bahwa profitabilitas berpengaruh negatif terhadap penerimaan opini audit going concern. Berdasarkan uraian di atas maka hipotesis ketiga adalah sebagai berikut:

H3: Profitabilitas berpengaruh negatif terhadap penerimaan opini audit going concern.

\subsubsection{Pengaruh Rencana Manajemen dengan Penerimaan Opini Audit Going Concern}

Dijelaskan dalam teori keagenan bahwa pemilik telah memberikan wewenang/ mendelegasikan tugas kepada manajemen (agen) (Jensen dan Meckling, 1976), berarti termasuk pula dalam hal pengambilan keputusan dalam rangka mengelola perusahaan. Keputusan yang diambil manajemen dalam menjalankan sebuah perusahaan mungkin saja tidak sesuai dengan kehendak dari pemegang saham. Hal ini disebabkan adanya perbedaan kepentingan diantara kedua belah pihak, yaitu pemilik (prinsipal) dan manajemen (agen) 
sehingga pemilik akan mengevaluasi pertanggungjawaban manajemen. Tugas untuk menilai kewajaran laporan keuangan yang merupakan hasil dari pertanggungjawaban manajemen dilakukan oleh pihak ketiga yang independen yaitu adalah auditor independen. Hasil penilaian kewajaran atas laporan keuangan yang dilakukan oleh auditor adalah berupa opini audit.

Auditor harus mempertimbangkan banyak informasi baik yang bersifat kuantitatif dan kualitatif dalam memberikan opininya, ini disebabkan karena auditor harus bertanggung jawab atas opini yang diterbitkan. Auditor juga berkewajiban untuk mengevaluasi kemampuan perusahaan dalam mempertahankan kelangsungan usahanya disamping menilai kewajaran dari laporan keuangan sebuah perusahaan. PSA 30 SA 341 (IAPI 2011) menyatakan bahwa apabila seorang auditor ragu atas kelangsungan hidup sebuah perusahaan, maka auditor harus mengetahui dan mengevaluasi rencana dari manajemen perusahaan. Setyowati (2013) menyatakan bahwa rencana manajemen yang dapat dianalisis oleh auditor adalah rencana manajemen berupa rencana emisi saham, rencana menarik hutang, rencana menjual aktiva, dan rencana mengurangi/menunda pengeluaran terhadap penerimaan opini audit going concern. Hasil penelitian Setyowati (2013) adalah bahwa rencana manajemen berupa strategi emisi saham dan strategi menarik/ merestrukturisasi hutang berpengaruh negatif terhadap penerimaan opini going concern. Berdasarkan uraian diatas, maka dengan adanya rencana manajemen maka akan semakin memperkecil penerimaan opini audit going concern bagi perusahaan, sehingga hipotesis keempat adalah sebagai berikut:

H4: Rencana manajemen berpengaruh negatif terhadap penerimaan opini audit going concern.

Gambar 1 berikut merupakan model penelitian ini:

Gambar 1. Model Penelitian

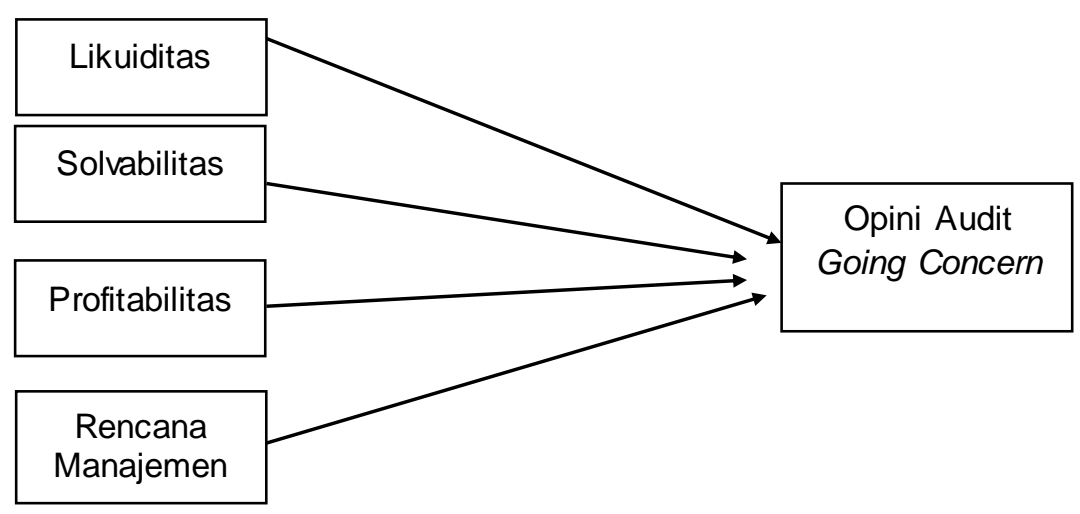




\section{Metodologi Penelitian}

\subsection{Definisi Operasional dan Pengukuran Variabel}

\subsubsection{Opini Audit Going Concern}

Opini audit going concern merupakan opini yang dikeluarkan auditor untuk memastikan apakah perusahaan dapat mempertahankan kelangsungan hidupnya (IAPI 2011). Variabel ini diukur menggunakan variabel dummy. Opini audit going concern diberi kode 1 (opini wajar tanpa pengecualian dengan bahasa penjelas, opini wajar dengan pengecualian, opini tidak wajar, atau tidak memperikan pendapat), dan opini audit non-going concern diberi kode 0 (opini wajar tanpa penggecualian). Untuk opini wajar tanpa pengecualian dengan bahasa penjelas dan wajar dengan pengecualian perlu dilihat apakah penjelasannya dikarenakan oleh going concernatau tidak. Jika penjelasannya bukan karena going concern maka akan diberi kode 0 .

\subsubsection{Likuiditas}

Rasio Likuiditas merupakan suatu indikator untuk mengukur kemampuan perusahaan untuk membayar semua kewajiban finansial jangka pendek pada saat jatuh tempo dengan menggunakan aktiva lancar yang tersedia (Syamsuddin 2001: 41). Dalam penelitian ini rasio likuiditas diproksikan dengan current ratio yang dirumuskan sebagai berikut:

$$
\text { current ratio }=\frac{\text { current assets }}{\text { current liabilities }}
$$

\subsubsection{Solvabilitas}

Rasio solvabilitas merupakan rasio yang mengukur sejauh mana aset perusahaan dibiayai dengan menggunakan dana dari kreditor dan modal dari para pemegang saham (Dewayanto 2011). Dalam penelitian ini solvabilitas diukur menggunakan debt to total assets, yang dirumuskan sebagai berikut:

$$
\text { debt to total assets }=\frac{\text { total liabilities }}{\text { total assets }}
$$

\subsubsection{Profitabilitas}

Profitabilitas merupakan rasio yang mengukur kemampuan perusahaan dalam menghasilkan keuntungan dengan seluruh aktiva yang tersedia (Syamsuddin 2001: 63). Dalam 
penelitian ini rasio profitabilitas diproksikan menggunakan return on assets (ROA), yang dirumuskan sebagai berikut:

$$
\text { return on assets }=\frac{\text { net income }}{\text { total assets }}
$$

\subsubsection{Rencana Manajemen}

Apabila muncul peristiwa yang menyebabkan auditor ragu atas kelangsungan hidup perusahaan, maka auditor bertanggung jawab untuk mengevaluasi apa rencana dari manajemen untuk mengatasi dampak dari peristiwa tersebut. Dalam penelitian ini rencana manajemen dinilai menggunakan variabel dummy. Dimana jika manajemen perusahaan memiliki rencana seperti merestrukturisasi hutang, menerbitkan saham, menjual aset tidak produktif, melakukan penghematan/efisiensi, dan rencana lainnya, maka diberikan kode 1, sedangkan jika manajemen perusahaan tidak memiliki rencana maka diberikan kode 0 .

\subsection{Populasi dan Sampel}

Populasi yang digunakan dalam penelitian ini adalah perusahaan manufaktur yang terdaftar dalam Bursa Efek Indonesia (BEI) tahun 2010-2012. Sampel diambil dengan menggunakan metode purposive sampling dari seluruh perusahaan manufaktur di Bursa Efek Indonesia (BEI) pada tahun 2010-2012. Proses pengambilan sampel dengan metode purposive sampling dari penelitian ini didasarkan pada beberapa kriteria yaitu:

1. Perusahaan manufaktur yang terdapat di BEI dari tahun 2010 sampai tahun 2012 dan menerbitkan laporan keuangan dari tahun 2010 sampai 2012 yang telah diaudit oleh auditor independen.

2. Laporan keuangan disajikan dengan menggunakan mata uang rupiah ( $R p)$.

3. Mengalami financial distress 3 periode berturut-turut saat pengamatan, dengan kriteria yang ditandai dengan salah satu kondisi berikut, yaitu modal kerja negatif, ekuitas negatif, laba operasi tahun berjalan negatif, atau laba bersih negatif atau perusahaan mengalami kerugian bersih.

\subsection{Teknik Analisis}

Pengujian hipotesis dalam penelitian ini menggunakan analisis multivariat dengan regresi logistik. Regresi logistik merupakan regresi yang digunakan sejauh mana probabilitas terjadinya variabel dependen dapat diprediksi dengan variabel independen. Dalam analisis regresi logistik 
tidak perlu lagi uji normalitas pada variabel bebasnya (Ghozali 2011: 333). Berdasarkan model penelitian di atas, maka persamaan dalam penelitian ini adalah sebagai berikut:

$$
\mathrm{GC}=\mathrm{a}+\mathrm{b}_{1} \mathrm{CR}+\mathrm{b}_{2} \mathrm{DTA}+\mathrm{b}_{3} \mathrm{ROA}+\mathrm{b}_{4} \mathrm{RM}+\mathrm{e}
$$

Keterangan:

$\mathrm{GC}=$ Opini audit going concern.

$\mathrm{CR}=$ Likuiditas.

DTA $=$ Solvabilitas.

$\mathrm{ROA}=$ Profitabilitas.

$\mathrm{RM}=$ Rencana Manajemen.

a $=$ Konstanta.

$\mathrm{e}=$ Error.

$b_{1}-b_{4}=\quad$ Koefisien regresi.

\section{Analisis dan Pembahasan}

Dari keseluruhan perusahaan manufaktur yang terdaftar dalam Bursa Efek Indonesia periode 2010-2012, terdapat 35 perusahaan yang memenuhi kriteria dalam penelitian. Tabel 1 berikut ini merupakan tabel penarikan sampel untuk penelitian ini.

Tabel 1. Penarikan Sampel Penelitian

\begin{tabular}{|c|l|c|}
\hline No. & \multicolumn{1}{|c|}{ Kriteria } & Jumlah \\
\hline 1 & $\begin{array}{l}\text { Perusahaan manufaktur yang terdaftar di BEl dari tahun 2010 sampai } \\
\text { tahun 2012 dan menerbitkan laporan keuangan yang telah diaudit oleh } \\
\text { auditor independen dari tahun 2010 sampai tahun 2012. }\end{array}$ & 108 \\
\hline 2 & $\begin{array}{l}\text { Perusahaan yang tidak menyajikan laporan keuangan dengan } \\
\text { menggunakan mata uang rupiah (Rp). }\end{array}$ & $(49)$ \\
\hline 3 & $\begin{array}{l}\text { Tidak mengalami masalah keuangan (financial distress) selama 3 } \\
\text { tahun berturut-turut. }\end{array}$ & 35 \\
\hline & Perusahaan yang digunakan. & 3 \\
\hline & Tahun penelitian. & 105 \\
\hline
\end{tabular}

Sumber: www.idx.co.id

Tabel 2 berikut ini merupakan statistik deskriptif:

Tabel 2. Deskripsi variabel likuiditas, solvabilitas dan profitabilitas

\begin{tabular}{|l|c|c|c|c|}
\hline Variabel & Minimum & Maximum & Rata-rata & Standar deviasi \\
\hline Likuiditas & 0,045 & 13,081 & 1,206 & 1,791 \\
\hline Solvabilitas & 0,230 & 5,025 & 0,978 & 0.798 \\
\hline Profitabilitas & $-0,756$ & 3,475 & 0,038 & 0.374 \\
\hline
\end{tabular}

Sumber: Output SPSS, yang telah diolah. 
Berdasarkan tabel 2 di atas dapat dijelaskan bahwa likuiditas merupakan suatu indikator mengenai kemampuan perusahaan untuk membayar semua kewajiban finansial jangka pendek pada saat jatuh tempo dengan menggunakan aktiva lancar yang tersedia, dimana nilai minimum sebesar 0,045 terdapat pada perusahaan PT Karwell Indonesia, Tbk. tahun 2010, sedangkan nilai tertinggi sebesar 13,081 terdapat pada perusahaan PT Jakarta Kyoi Steel Works, Tbk. tahun 2010, kemudian nilai rata-rata sebesar 1,206 dan nilai standar deviasi sebesar 1,791 menunjukkan kemampuan perusahaan sampel secara rata-rata dapat memenuhi kewajiban finansial jangka pendek yang dimiliki oleh perusahaan tersebut.

Solvabilitas merupakan rasio yang digunakan untuk mengetahui seberapa besar aktiva yang dibiayai dengan menggunakan dana dari kreditor, dimana nilai minimum sebesar 0,230 terdapat pada perusahaan PT Samindo Resources, Tbk. tahun 2010, sedangkan nilai tertinggi sebesar 5,025 terdapat pada perusahaan PT Karwell Indonesia, Tbk. tahun 2011, kemudian nilai rata-rata sebesar 0,978 dan nilai standar deviasi sebesar 0,798 menunjukkan bahwa pendanaan perusahaan sampel secara rata-rata diperoleh dengan pinjaman dari kreditor.

Profitabilitas merupakan salah satu rasio yang digunakan untuk mengukur keberhasilan perusahaan untuk dapat menghasilkan laba, dimana nilai minimum sebesar -0,756 terdapat pada perusahaan PT Alam Karya Unggul, Tbk. tahun 2011, sedangkan nilai tertinggi sebesar 3,475 terdapat pada perusahaan PT Karwell Indonesia, Tbk. tahun 2011, kemudian nilai ratarata sebesar 0,038 dan nilai standar deviasi sebesar 0,374 menunjukkan perusahaan sampel secara rata-rata masih dapat menghasilkan laba untuk mempertahankan kelangsungan usahanya.

Data deskriptif untuk variabel opini audit dan rencana manajemen dapat dilihat pada Tabel 3 berikut ini:

Tabel 3. Deskripsi Variabel Opini Audit dan Rencana Manajemen

\begin{tabular}{|l|l|c|c|}
\hline \multicolumn{2}{|c|}{ Variabel } & Frequency & Percent \\
\hline \multirow{3}{*}{ Opini Audit } & Opini audit non going concern & 65 & 61,9 \\
\cline { 2 - 4 } & Opini audit going concern & 40 & 38,1 \\
\cline { 2 - 4 } & Total & 105 & 100 \\
\hline \multirow{2}{*}{$\begin{array}{l}\text { Rencana } \\
\text { Manajemen }\end{array}$} & Memiliki rencana & 55 & 52,4 \\
\cline { 2 - 4 } & Tidak memiliki rencana & 50 & 47,6 \\
\cline { 2 - 4 } & Total & 105 & 100 \\
\hline
\end{tabular}

Sumber: Output SPSS, yang telah diolah.

Berdasarkan Tabel 3 di atas dapat dijelaskan bahwa perusahaan yang mendapatkan opini audit non going concern sebanyak 65 perusahaan $(61,9 \%)$, sedangkan perusahaan yang mendapatkan opini audit going concern sebesar 40 perusahaan $(38,1 \%)$. Hal ini menunjukkan bahwa opini yang dikeluarkan auditor dapat menggambarkan keadaan yang sesungguhnya agar para pengguna laporan keuangan tidak salah dalam mengambil keputusan bisnisnya.

Perusahaan yang memiliki rencana manajemen sebanyak 55 perusahaan (52,4\%), sedangkan perusahaan yang tidak memiliki rencana manajemen sebesar 50 perusahaan 
(47,6\%). Hal ini menunjukkan bahwa rencana dari manajemen sangat diperlukan untuk perusahaan yang sedang mengalami masalah. Artinya adalah bahwa dengan adanya rencana tersebut maka diharapkan masalah perusahaan dapat teratasi, sehingga kegiatan sehari-hari perusahaan tidak terganggu.

Hasil regresi logistik Keseluruhan Model dapat dilihat pada Tabel 4.

Tabel 4. Hasil Uji Model Fit

\begin{tabular}{|c|c|}
\hline & -2 Log Likelihood \\
\hline Beginning Blok 0 & 139,551 \\
\hline Beginning Blok 1 & 46,645 \\
\hline
\end{tabular}

Sumber: Output SPSS, yang

Berdasarkan Tabel 4 di atas diketahui bahwa nilai statistik -2LogL sebesar 139,551 setelah dimasukkan empat variable nilai -2LogL turun menjadi 46,645. Hal ini menunjukkan bahwa dengan menambah variable likuiditas, solvabilitas, profitabilitas dan rencana manajemen bisa memperbaiki model fit.

Hasil koefisien determinasi dapat dilihat pada tabel 5 berikut ini:

Tabel 5 : Model Summary Koefisien Determinasi

\begin{tabular}{|c|c|c|c|}
\hline Step & -2 Log Likelihood & $\begin{array}{c}\text { Cox \& Snell R } \\
\text { Square }\end{array}$ & Nagelkerke R Square \\
\hline 1 & 46,645 & 0,587 & 0,799 \\
\hline
\end{tabular}

Sumber: Output SPSS, yang telah diolah

Berdasarkan Tabel 4.5 diketahui nilai Cox dan Snell's $R$ square sebesar 0,587 dan nilai Nagelkerke $\mathrm{R}$ Square sebesar 0,799 menunjukkan bahwa likuiditas, solvabilitas, profitabilitas dan rencana manajemen menjelaskan opini auditor sebesar $79,9 \%$, sedangkan $20,1 \%$ dipengaruhi oleh variabel lain yang tidak ada dalam persamaan regresi logistik tersebut.

Tabel 6 berikut ini merupakan tabel untuk menguji kelayakan model regresi dengan menggunakan Hosmer and Lemeshow's test.

Tabel 6. Hosmer and Lemeshow's Test

\begin{tabular}{|c|c|c|c|}
\hline Step & Chi-square & Df & Sig. \\
\hline 1 & 3,420 & 8 & 0,905 \\
\hline \multicolumn{4}{|c}{} \\
Sumber: Output SPSS, yang telah diolah.
\end{tabular}

Berdasarkan Tabel 6 di atas diperoleh nilai statistik Hosmer and Lemeshow's goodness of fit sebesar 3,420 dengan probabilitas error 0,905 lebih besar dari 0,05. Hal ini menunjukkan bahwa model mampu memprediksi nilai observasinya atau dapat dikatakan model dapat diterima karena cocok dengan data observasinya, maka model dikatakan Fit dan model dapat diterima.

Tabel 7 berikut ini merupakan matriks klasifikasi yang menunjukkan kekuatan prediksi dari model regresi untuk memprediksi adanya opini audit. Tabel 7 menunjukkan bahwa menurut 
prediksi, perusahaan yang memperoleh opini audit going concern sebanyak 33 perusahaan, sedangkan observasi sesungguhnya menunjukkan sebanyak 40 perusahaan memperoleh opini audit going concern. Jadi dapat disimpulkan bahwa ketepatan model prediksi untuk opini audit going concern adalah $33 / 40$ atau $82,5 \%$. Di sisi lain perusahaan yang diprediksi memperoleh opini audit non going concern sebanyak 58 perusahaan, sedangkan observasi sesungguhnya menunjukkan bahwa terdapat 65 perusahaan memperoleh opini audit non going concern. Jadi dapat disimpulkan bahwa ketepatan model prediksi untuk opini audit non going concern adalah $58 / 65$ atau $89,2 \%$. Dengan demikian maka dapat disimpulkan bahwa ketepatan model dalam memprediksi variabel dependen, dalam hal ini adalah opini audit sebesar 86,7\%.

Tabel 7. Tabel Klasifikasi

\begin{tabular}{|c|c|c|c|}
\hline \multirow{2}{*}{ Observed } & \multicolumn{2}{|c|}{ Predicted } \\
\cline { 2 - 4 } & Non Going Concern & Going Concern & \multirow{2}{*}{ Percentage Correct } \\
\cline { 2 - 4 } & & & \\
\hline Non Going Concern & 58 & 7 & 89,2 \\
\hline Going Concern & 7 & 33 & 82,5 \\
\hline & & & 86,7 \\
\hline
\end{tabular}

Sumber: Output SPSS, yang telah diolah.

Tabel 8 berikut ini merupakan hasil analisis dari regresi logistik.

Tabel 8. Hasil Analisis Regresi Logistik

\begin{tabular}{|l|r|r|r|r|}
\hline \multicolumn{1}{|c|}{ Variabel } & \multicolumn{1}{c|}{ B } & \multicolumn{1}{c|}{ Wald } & \multicolumn{1}{c|}{ Sig. } & \multicolumn{1}{|c|}{$\operatorname{Exp}(\mathrm{B})$} \\
\hline CR & $-0,396$ & 1,969 & 0,161 & 0,673 \\
\hline DTA & 3,816 & 6,671 & 0,010 & 45,403 \\
\hline ROA & 2,238 & 0,365 & 0,546 & 9,375 \\
\hline RM & 5,002 & 16,663 & 0,000 & 148,755 \\
\hline Constant & $-6,380$ & 18,094 & 0,000 & 0,002 \\
\hline Variabel Terikat & Opini audit going concern \\
\hline
\end{tabular}

Sumber: Output SPSS, yang telah diolah.

Berdasarkan Tabel 8 di atas diperoleh persamaan regresi logistik sebagai berikut:

$$
\mathrm{GC}=-6,380-0,396 \mathrm{CR}+3,816 \mathrm{DTA}+2,238 \mathrm{ROA}+5,002 \mathrm{RM}
$$

Persamaan di atas dapat dijelaskan sebagai bahwa koefisien regresi likuiditas memiliki nilai sebesar -0,396 artinya berpengaruh negatif terhadap opini audit going concern. Artinya jika likuiditas yang diproksikan dengan current ratio mengalami penurunan, maka opini audit going concern akan mengalami kenaikan sebesar 0,396. Selain itu setiap penurunan likuiditas yang diproksikan dengan current ratio akan memberikan probabilitas kemungkinan opini audit going concern 0,673 kali lebih besar dibandingkan dengan opini audit non going concern. Berdasarkan Tabel 8, diketahui bahwa likuiditas tidak berpengaruh terhadap penerimaan opini audit going concern, sehingga hipotesis yang menyatakan bahwa likuiditas berpengaruh negatif terhadap opini audit going concern tidak terdukung. Hal ini menunjukkan bahwa auditor dalam 
memberikan opini audit going concern tidak hanya melihat kemampuan perusahaan tersebut dalam memenuhi kewajiban jangka pendeknya menggunakan aset lancar yang dimiliki, akan tetapi lebih cenderung melihat kondisi keuangan secara keseluruhan (Susanto 2009). Likuiditas yang diproksikan dengan current ratio tidak dapat dijadikan tolak ukur yang pasti untuk menentukan kelangsungan usaha sebuah perusahaan, namun, current ratio dapat dijadikan sebagai alat bantu dalam mengukur kondisi keuangan perusahaan (Susanto 2009 dan Hani et al., 2003 dalam Susanto 2009). Temuan ini mendukung hasil dari penelitian Susanto (2009) dan Sussanto dan Aquariza (2012) menyatakan bahwa likuiditas yang diproksikan dengan current ratio tidak mempengaruhi auditor dalam memberikan opini audit going concern. Namun hasil penelitian ini tidak mendukung hasil penelitian Januarti dan Fitrianasari (2008) yang menyatakan bahwa likuiditas yang diproksikan dengan current ratio mempengaruhi auditor dalam memberikan opini audit going concern.

Koefisien regresi solvabilitas yang diproksikan dengan debt to total asstes memiliki nilai sebesar 3,816 artinya berpengaruh positif terhadap opini audit going concern. Artinya jika solvabilitas yang diproksikan dengan debt to total asstes mengalami kenaikan, maka opini audit going concern akan mengalami kenaikan sebesar 3,816. Selain itu setiap kenaikan solvabilitas yang diproksikan dengan debt to total asstes akan memberikan probabilitas kemungkinan opini audit going concern 45,403 kali lebih besar dibandingkan dengan opini audit non going concern. Berdasarkan Tabel 8 diketahui bahwa solvabilitas berpengaruh positif terhadap penerimaan opini audit going concern, sehingga hipotesis yang menyatakan bahwa solvabilitas berpengaruh positif terhadap opini audit going concern diterima. Tabel 8 menunjukkan bahwa semakin besar solvabilitas perusahaan, maka auditor akan cenderung memberikan opini audit going concern. Artinya semakin besar solvabilitas sebuah perusahaan maka semakin besar juga kewajiban yang dimiliki oleh perusahaan, sehingga perusahaan akan dianggap tidak menguntungkan dalam jangka panjang dan harus diresturkturisasi namun yang sering terjadi setelah perusahaan diresrukturisasi adalah perusahaan menjadi bangkrut (Sutedja 2010). Selain itu perusahaan dengan solvabilitas yang tinggi cenderung menghadapi bahaya kebangkrutan karena nilai aset yang dimiliki perusahaan lebih kecil dibandingkan dengan kewajiban yang dimiliki perusahaan, hal ini dapat menyebabkan timbulnya ketidakpastian kelangsungan hidup perusahaan sehingga perusahaan berpeluang untuk mendapatkan opini audit going concern dari auditor (Susanto 2009). Temuan ini mendukung hasil penelitian dari Susanto (2009), Sussanto dan Aquariza (2012), dan Sutedja (2010) yang menyatakan bahwa solvabilitas yang diproksikan dengan debt to assets ratio berpengaruh positif terhadap pemberian opini going concern dari auditor. Namun hasil penelitian ini tidak mendukung hasil penelitian Rudyawan dan Badera (2009) yang menyatakan bahwa solvabilitas yang diproksikan dengan debt to assets ratio tidak mempengaruhi auditor dalam memberikan opini going concern. 
Koefisien regresi profitabilitas yang diproksikan dengan return on assets memiliki nilai sebesar 2,238 artinya berpengaruh positif terhadap opini audit going concern. Artinya jika profitabilitas yang diproksikan dengan return on assets mengalami kenaikan, maka opini audit going concern akan mengalami kenaikan sebesar 2,238. Selain itu setiap kenaikan profitabilitas yang diproksikan dengan return on assets akan memberikan probabilitas kemungkinan opini audit going concern 9,375 kali lebih besar dibandingkan dengan opini audit non going concern. Berdasarkan Tabel 8, diketahui bahwa profitabilitas tidak berpengaruh terhadap penerimaan opini audit going concern, sehingga hipotesis yang menyatakan bahwa profitabilitas berpengaruh negatif terhadap opini audit going concern ditolak. Rasio profitabilitas dipengaruhi oleh keefektifan manajemen dalam mengelola sumber daya yang dimiliki. Tidak ditemukannya hubungan yang signifikan antara profitabilitas dengan opini audit going concern disebabkan karena financial leverage yang ditanggung perusahaan relatif besar, atau dengan kata lain peningkatan laba yang diperoleh perusahaan tidak diimbangi dengan penurunan kewajiban yang dimiliki oleh perusahaan (Januarti dan Fitrianasari 2008). Temuan ini mendukung hasil penelitian dari Januarti dan Fitrianasari (2008) dan Sussanto dan Aquariza (2012) yang menyatakan bahwa profitabilitas yang diproksikan dengan return on assets tidak berpengaruh terhadap pemberian opini going concern dari auditor. Namun hasil penelitian ini tidak mendukung penelitian Susanto (2009), Kristiana (2012) dan Sutedja (2010) yang menyatakan bahwa profitabilitas yang diproksikan dengan return on assets berpengaruh terhadap pemberian opini going concern dari auditor.

Koefisien regresi rencana manajemen sebesar 5,002 artinya berpengaruh positif terhadap opini audit going concern. Artinya jika rencana manajemen mengalami kenaikan, maka opini audit going concern akan mengalami kenaikan sebesar 5,002. Selain itu setiap kenaikan rencana manajemen akan memberikan probabilitas kemungkinan opini audit going concern 148,755 kali lebih besar dibandingkan dengan opini audit non going concern. Berdasarkan Tabel 8, diketahui bahwa rencana manajemen berpengaruh positif terhadap penerimaan opini audit going concern, sehingga hipotesis yang menyatakan bahwa rencana manajemen berpengaruh positif terhadap opini audit going concern berhasil didukung. Apabila dikaitkan dengan opini audit, maka dengan adanya rencana manajemen maka hal tersebut menjadi indikasi bahwa perusahaan sedang mengalami masalah keuangan, karena laporan keuangan disusun menggunakan asumsi going concern, dimana artinya perusahaan akan melanjutkan operasinya. Hasil regresi menunjukkan bahwa dengan adanya rencana dari manajemen perusahaan maka semakin memperkuat dugaan auditor bahwa perusahaan tersebut sedang mengalami masalah yang dapat mengancam kelangsungan usahanya. Temuan ini mendukung hasil penelitian Setyowati (2013) yang menyatakan bahwa terdapat rencana manajemen yang 
dapat berpengaruh positif terhadap opini audit going concern diantaranya adalah rencana manajemen untuk melakukan pengurangan atau penghematan biaya.

\section{Kesimpulan, Keterbatasan, dan Saran}

\subsection{Kesimpulan}

Kesimpulan dalam penelitian ini adalah sebagai berikut:

1. Likuiditas tidak berpengaruh terhadap penerimaan opini audit going concern. Artinya bahwa likuiditas tidak dapat digunakan sebagai satu-satunya dasar bagi auditor untuk menentukan munculnya opini audit going concern karena dalam penentuan terbitnya opini audit going concern, auditor tidak hanya akan melihat likuiditas saja melainkan kondisi keuangan perusahaan secara keseluruhan.

2. Solvabilitas berpengaruh positif terhadap penerimaan opini audit going concern. Hal ini menunjukkan bahwa semakin besar solvabilitas yang dimiliki perusahaan maka auditor cenderung akan memberikan opini audit going concern, karena perusahaan yang memiliki solvabilitas yang tinggi dipandang sebagai perusahaan yang tidak menguntungkan dalam jangka waktu panjang dan harus direstrukturisasi. Solvabilitas yang tinggi mengartikan bahwa semakin banyak aset perusahaan yang didanai lewat pinjaman. Hal ini menjadikan perhatian bagi auditor karena manajemen berusaha untuk meningkatkan aset perusahaan agar dapat menarik investor dan kreditor sehingga kemungkinan perusahaan untuk melunasi aset-asetnya akan menjadi semakin sulit. Dengan demikian, auditor akan cenderung untuk menerbitkan opini audit going concern untuk solvabilitas yang meningkat.

3. Profitabilitas tidak berpengaruh terhadap penerimaan opini audit going concern. Tidak ditemukannya hubungan yang signifikan antara profitabilitas dengan opini audit going concern disebabkan karena financial leverage yang ditanggung perusahaan relatif tinggi, atau dengan kata lain peningkatan laba yang diperoleh perusahaan tidak diimbangi dengan penurunan kewajiban yang dimiliki oleh perusahaan. Selain itu, auditor tidak hanya mendasarkan pada profitabilitas untuk menerbitkan opini audit going concern, namun auditor juga akan melihat dan menganalisis seluruh rasio keuangan perusahaan dalam rangka penerbitan opini audit going concern.

4. Rencana manajemen berpengaruh positif terhadap penerimaan opini audit going concern. Dengan adanya rencana dari manajemen sebuah perusahaan, maka itu dapat menguatkan dugaan dari auditor bahwa perusahaan tersebut sedang mengalami masalah yang mungkin saja dapat mengancam kelangsungan usahanya. Hal ini karena rencana manajemen adalah sebagai dasar upaya manajemen dalam mempertahankan kelangsungan usaha perusahaan 
sehingga auditor akan menerbitkan opini audit going concern dalam merespon dan menganalisis upaya manajemen untuk mempertahankan kelangsungan usaha perusahaan.

Hasil penelitian ini dapat memberikan penjelasan bahwa penerbitan opini audit going concern yang dilakukan oleh auditor dipengaruhi oleh solvabilitas dan rencana manajemen. Solvabilitas dan rencana manajemen merupakan komponen penting yang dapat mempengaruhi kelangsungan usaha perusahaan karena itu auditor akan menganalisis lebih mendalam mengenai solvabilitas serta rencana manajemen. Namun selain itu berdasarkan hasil penelitian ini, auditor juga akan lebih menekankan pada menganalisis kondisi keuangan perusahaan secara keseluruhan dibandingkan dengan hanya menganalisis pada likuiditas dan profitabilitas saja.

\subsection{Keterbatasan}

Sampel yang digunakan dalam penelitian ini adalah perusahaan manufaktur yang terdaftar dalam Bursa Efek Indonesia (BEI), dimana periode dalam penelitian ini adalah 2010 sampai 2012, sehingga hasil penelitian ini hanya menggambarkan kondisi perusahaan manufaktur untuk periode 2010 sampai 2012. Serta variabel yang digunakan dalam penelitian ini hanya 4 variabel yaitu likuiditas yang diproksikan dengan current ratio, solvabilitas yang diproksikan dengan debt to assets, profitabilitas yang diproksikan dengan return on assets dan rencana manajemen.

\subsection{Saran}

Dari keterbatasan tersebut, maka diharapkan penelitian-penelitian selanjutnya disarankan:

1. Penelitian selanjutnya dapat diharapkan untuk meneliti perusahaan di sektor lainnya selain sektor manufaktur.

2. Penelitian selanjutnya diharapkan dapat memperpanjang jumlah tahun pengamatan.

3. Penelitian selanjutnya diharapkan dapat menambahkan variabel lainnya yang mempengaruhi penerimaan opini audit going concern.

\section{Daftar Pustaka}

Arens, Alvin A., Randal J. Elder., Mark S. Beasley., Amir Abadi Jusuf. 2011. Audit dan Jasa Assurance: Pendekatan Terpadu (Adaptasi Indonesia). Jakarta: Salemba Empat.

Ghozali, I. 2011. Aplikasi Analisis Multivariate dengan Program IBM SPSS 19. Semarang: Badan Penerbit Universitas Diponegoro. 
Institut Akuntan Publik Indonesia (IAPI). 2011. Pertimbangan Auditor atas Kemampuan Entitas dalam Mempertahankan Kelangsungan Hidupnya, PSA No. 30. Standar Profesional Akuntan Publik (SPAP). Jakarta.

Januarti, I., dan E. Fitrianasari. 2008. Analisis Rasio Keuangan dan Rasio Non Keuangan yang Mempengaruhi Auditor dalam Memberrikan Opini Audit Going Concern pada auditee. Jurnal MAKSI. Vol. 8, No. 1, Januari: 43-58.

Jensen, Michael C. dan William H. Meckling. 1976. Theory of the Firm: Managerial Behavior, Agency Costs and Ownership Structure. Social Science Research Network. http://papers.ssrn.com/abstract=94043 (diakses tanggal 16 Februari 2015).

Kristiana, I. 2012. Pengaruh Ukuran Perusahaan, Profitabilitas, Likuiditas, Pertumbuhan Perusahaan terhadap Opini Audit Going Concern pada Perusahaan Manufaktur yang Terdaftar di Bursa Efek Indonesis (BEl). Berkala Ilmiah Mahasiswa Akuntansi. Vol. 1, No. 1, Januari: 47-51.

Rudyawan, Arry P., dan I.D. Nyoman Badera. 2009. Opini Audit Going Concern: Kajian Berdasarkan Model Prediksi Kebangkrutan, Pertumbuhan Perusahaan, Leverage dan Reputasi Auditor. Jurnal Akuntansi dan Bisnis, Vol. 4, No.2, Juli: 129-138.

Setyowati, W. 2013. Strategi Manajemen Berbasis Keuangan sebagai Faktor Mitigasi dalam Penerimaan Keputusan Opini Going Concern. Jurnal Ekonomi dan Bisnis, Tahun. XXIII, No. 1, April: 63-75.

Sundjaja, R. S., dan Inge Barlian. 2003. Manajemen Keuangan: Perencanaan dan Analisis Keuangan. Jakarta: Literata Lintas Media.

Susanto, Y. K. 2009. Faktor-faktor yang Mempengaruhi Penerimaan Opini Audit Going Concern pada Perusahaan Publik Sektor Manufaktur. Jurnal Bisnis dan Akuntansi, Vol. 11, No.3, Desember: 155-173.

Sussanto, H., dan Nur Mettani Aquariza. 2012. Analisis Pengaruh Opini Audit Tahun Sebelumnya, Kualitas Auditor, Profitabilitas, Likuiditas dan Solvabilitas terhadap Pemberian Opini Audit Going Concern pada Perusahaan Consumer Goods Industry yang Terdaftar di Bursa Efek Indonesia. UG Jurnal, Vol. 6, No. 12, HIm: 14-19.

Sutedja, C. 2010. Faktor-faktor yang Berpengaruh terhadap Pemberian Opini Audit Going Concern Pada perusahaan Manufaktur. Jurnal Akuntansi Kontemporer. Vol. 2, No. 2, Juli: 153-168.

Syamsuddin, L. 2001. Manajemen Keuangan Perusahaan: Perencanaan, Pengawasan dan Pengambilan Keputusan. Jakarta: PT. Raja Grafindo Persada. 